液晶空間光変調器とそのコヒーレント光データ処理応用

\title{
Liquid Crystal Light Valves
}

\author{
J. Grinberg*, W. P. Bleha*, P. O. Braatz*, U. Efron*, N. W. Goodwin* \\ and M. J. Little*
}

(訳) 栖 原 敏 明**

\section{要 約}

ヒューズ研究所 (Hughes Research Laboratories）でこの10年間に開発されてきた液晶 光バルブ（LCLV）について概説する。CdSや $\mathrm{Si}$ 用いた光入力型の光バルブや, CCD 駆動 の光バルブにつき, その構造, 動作と性能を説 明する。又, 情報処理システム，ディスプレイ システムへの応用例についても述べる。

\section{1. まえがき}

ここで述べる咣バルブとは光ビームに空間的 な変調を加えて読み出すことを可能にするデバ イスである。この種のデバイスは画像増幅器ま たは画像変換器 (又はその両方) として用いる ことができる。画像増幅器としての使用の一例 は図 1 に示すような大スクリーンへの投影シス テムである。小さく（25～50mm）て輝度の低い ブラウン管 $(\mathrm{CRT})$ を光バルブに画像を入力す るために用い, 高輝度の光源を用いれば，その

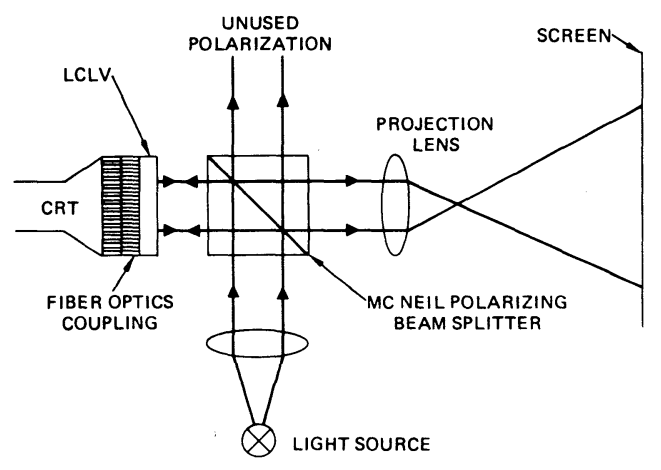

図 1 大スクリーンへの投影システム

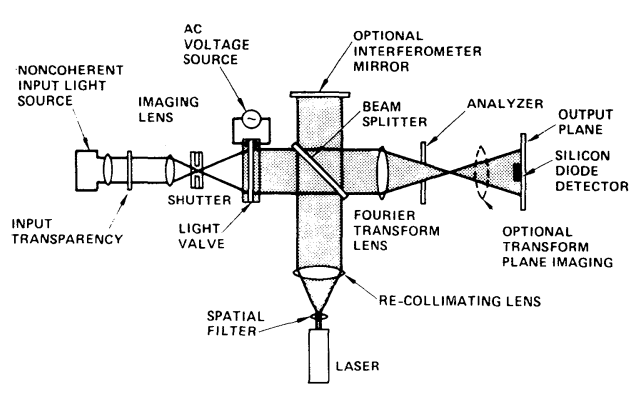

困2 汎用コヒーレント光学系テストベンチ

画像を大きなスクリーンに投影することができ る。画像変換器としての代表的な応用例は図 2 のような光情報処理のためのノンコヒーレント ーコヒーレント画像変換器である。このデバイ スは読み出し光源としてレーザーを用いること により，C R T上のノンコヒーレント（非干渉） な画像をコヒーレント (可干渉) な画像に変換 する。画像変換の他の一例としては波長変換,

例えば赤外線ミサイル追跡装置の動的試験に用 いられる可視一赤外画像変換器などが挙げられ る。このようなシステムでは画像は可視 C R T から光バルブに入力され，赤外光により読み出 される。画像変換器のいま一つの例は電気的に 駆動する光バルブであり，この場合には時系列 の電気信号が任意の光波長域での並列的な光画 像に変換される。

本稿では，3つの世代に分けられるヒューズ の液晶光バルブ（LCLV）について述べる。こ れらは全て反射モードで作動し，2．で説明す るハイブリッド電界効果モードで駆動する液晶

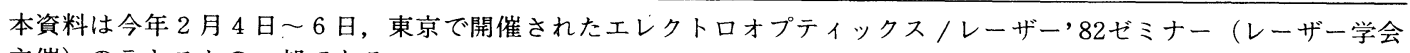
主催）のテキストの一部である。

* Hughes Research Laboratories, 3011 Malibu, Canyon Rd. Malibu, California 90265

**大阪大学工学部電子工学科 ( 5565 吹田市山田丘 $2-1$ ) 
を用いている。動作原理を簡単に述べると, 先 ず，液晶層が十分な大きさの信号電流により駆 動されると, 入力光の偏光ベクトルが電気信号 の大きさに比例した角度だけ回転する。従って 反射した出力光ビームには偏光角の空間的な変 調が加わることになる。この偏光変調のパター ンは，アナライザ（検光子）として通常の偏光 フィルム又は偏光ビームスプリッ夕を用いるこ とにより, 強度変調された出力画像に変換され る。3．および4.ではそれぞれ CdS, Siを用 いた光入力型のデバイスについて述べ，5．で は電気的駆動の光バルブすなわち $\mathrm{CCD} / \mathrm{LCLV}$ について述べる。6.ではこれらの光バルブの 代表的な応用例について説明する。

\section{2. ハイブリッド電界効果モード}

本稿で述べるデバイスは液晶を光変調媒質と して用いている。液晶は優れた電気光学効果 $(\mathrm{EO})$ 材料であり，1）複屈折が顕著 $(\Delta \mathrm{n}=$ $0.1 \sim 0.25), 2$ ) 誘電異方性が大きい $(\Delta \varepsilon=$ 3 １5），3）EO効果に闇值電圧がある，4） 液体であるの 4 項目の重要な特徵を持っている。

複屈折が大きいため非常に薄い液晶層 $\left(\mathrm{KD}_{2}\right.$ $\mathrm{PO}_{4}$ や $\mathrm{Bi}_{12} \mathrm{SiO}_{20}$ 等の結晶の場合は $0.1 \sim 1 \mathrm{~mm}$ 必要であるのに対し液晶では1.5〜 $12 \mu \mathrm{m})$ でデ バイスを構成でき, 従って光受容角を大きくと った場合でも高い分解能を実現することができ る。さらに液晶層が薄いことは駆動回路が中程 度のインピーダンスを有するものでよいことと なり, 駆動回路構成が容易となる。薄い液晶層 と大きな誘電異方性の組合せは低電圧（先述の 材料では200〜2000V必要であるのに対し1〜20 V ) での作動を可能にし, 又, 中程度のインピ ーダンスであることとから非常に小さな電力し か必要としないことになる。図 3 に示すような $\mathrm{EO}$ 効果の閾值電圧が存在することで駆動回路 の構成は更に容易になる。又，このため駆動回 路に比較的大きな漏れ電流があっても出力画像 のダイナミックレンジ（コントラスト）には殆 んど影響を与えない。例えば著者らは $1 ： 1$ の 信号対漏れ電流比しかない場合でも $100: 10$ 出 カスクリーン上コントラスト比を得ている。更

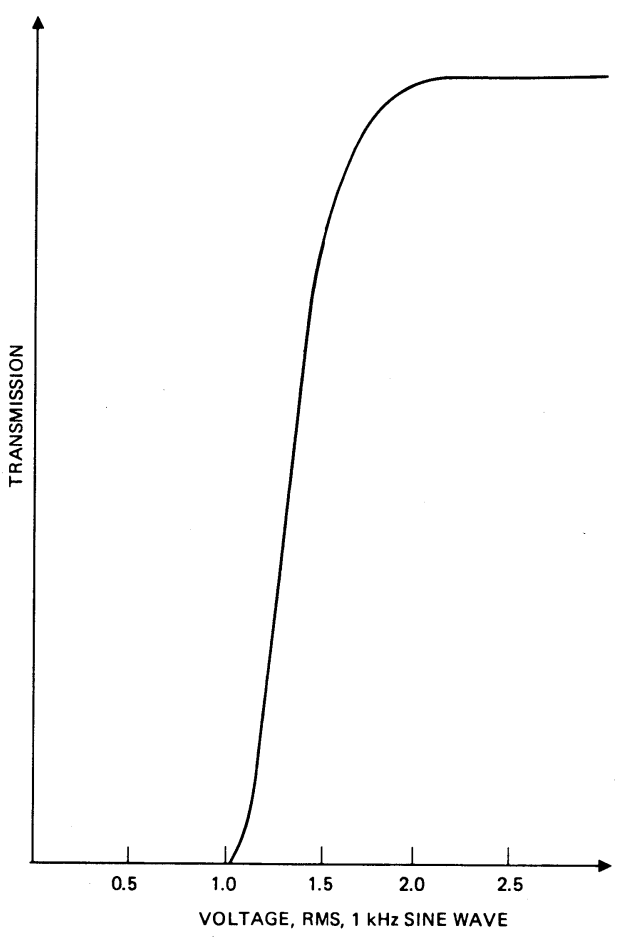

図 3 液晶の電気光学効果にみられる電圧闇值

に液晶の使用により, $\mathrm{KD}_{2} \mathrm{PO}_{4}$ や $\mathrm{Bi}_{12} \mathrm{SiO}_{20}$ の 場合のような大きな結晶を成長させることや大 面積 $(50 \mathrm{~mm})$ の薄い板に研摩する工程が不必要 となる。

液晶には幾つかの電気光学 $(\mathrm{EO})$ 効果がある。 最もよく知られているものはダイナミックスキ ヤッタリングと $2 つ の$ 電界効果であり, 電界効 果には単純な複屈折効果とツイストネマティッ ク効果がある。電界効果はダイナミックスキャ ッタリングに比べ薄い液晶層を用いることがで きるので応答速度が速く, 又高いコントラスト を得る可能性がある。複屈折効果を利用するに は基板に平行なホモジェニアス配向と垂直なホ メオトロピック配向のいずれをも用いることが できるが, ホモジェニアス配向ではディスプレ イシステムに要求される黒のバックグラウンド を得ることができない。ホメオトロピック配向 ではOFF 状態で黒のバックグラウンドを得るこ とができるが，均質な O N 状態を実現するには わずかにプレティルト角を持させた配向が必要 である”著者らはこのプレティルト角は強い読 
み出し光に対しては不安定であることを明らか にした。通常のッイストネマティック配向は反 射モードでは作動しないのでここで述べる光バ ルブには適用できない。強い読み出しビームか らフォトコンダクタやCCD ドライブといった画 像入力部を分離するためには出来るだけ反射モ 一ドを用いることが望ましい。そこでこれらの 全ての要求を満たすため, 著者らは八イブリッ ド電界効果モード（HYFEM）を用いたデバイ スを構成することにした。

このハイブリッド電気光学効果を実際に応用 するために，著者らはツイスト配向の液晶層を 作製した。すなわち，液晶は電極位置でその分 子長軸が電極面に平行（ホモジェニアス配向） となるよう配列している。さらに液晶分子はデ バイスの配向処理方向に沿って互いに平行に配 向されている。ツイスト配向状態を実現するに は， 2 枚の電極板の方向を，それぞれの電極面 上での液晶配向方向が互いに或る鋭角をなすよ うにすればよい。罒4に45ッイストの場合を

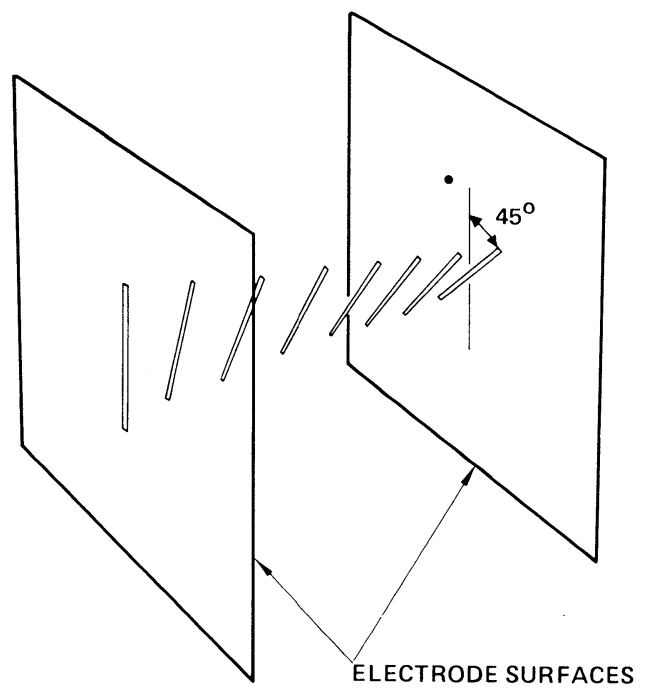

図445ッイストネマティック液晶配列（ハイブリッ ド電界効果) の概略図

ボしたように，電極間の液晶層内部では液晶分 子軸は滑らかに回転している。このッイスト配 向と液晶個有の複屈折性により, 直線偏光の光 が入射したときその偏光方向はツイスト角だけ 回転する。これがいわゆるッイストネマティッ
ク効果であるが，通常のツイストネマティック 効果デバイスではツイスト角は $90^{\circ}$ であるのに 対し，上述したように著者らのデバイスのツイ スト角は $45^{\circ}$ である。

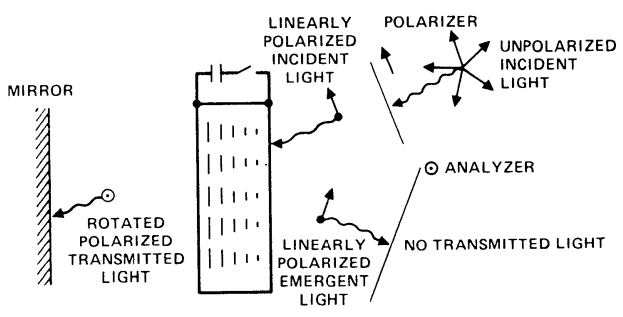

a) OFF-STATE

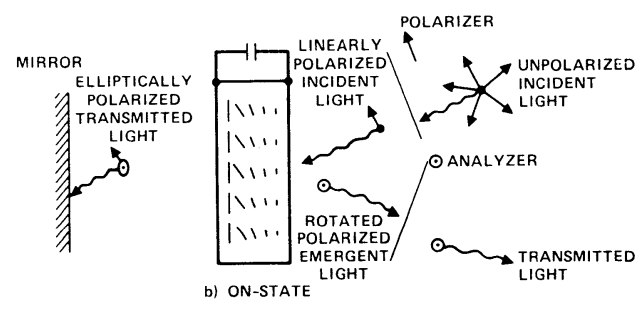

図 5 ハイブリッド電界効果モード光バルブの動作 :
（a） OFF 状態，（b） ON状態

ハイブリッド電界効果モードの動作を説明す るために先ずOFF状態を考える。図 5 （a）の ように光バルブと読み出し光源の間に直交した ポラライザ/アナライザ対を置く。ポラライザ は入射ビーム光路中に軸が入射側電極板の配向 方向と平行になるように置き，アナライザは反 射ビームの光路中に置く。直線偏光にされた入 射光は液晶層を通過することによりその偏光方 向が $45^{\circ}$ 回転するが，誘電体ミラーにより反射 して再び液晶層を通過する際には逆方向に $45^{\circ}$ 回転して入射光と同方向の偏光に戻るので，入 射側のポラライザと直交するアナライザにより 遮光される。このため OF F 状態は暗状態とす ることができる。これから分るようにデバイス のOF F 状態は全くッイストネマティック効果 で支配されている。

これに対し O N 状態はやや複雑である。電界 を印加して正の誘電異方性をもつ液晶分子を基 板に垂直（ホメオトロピック）な方向に回転さ せれば，入射光の偏光は液晶により影響されな くなり, OFF状態と同様に ON状態も暗状態と 
なるであろう。しかしこれでは何にもならない。 しかし，このプロセスを更に注意深く観察すれ ば，完全な“OFF”状態と完全な“ON” 状態 の中間にデバイスが直交アナライザを通して光 ・を誘過させる電圧領域があることが分る。液晶 に電圧が印加される際に, 液晶分子はホメオト ロピック配向に近付くように傾斜する（図 5(b) 参照)。このような分子軸方向（基板に平行と垂 直の中間）では, 分子の複屈折性により光の偏 光に影響が生じる。その結果, この中間的な電 圧ではミラーで反射後デバイスから出射する光 はもはや直線偏光ではなくなり, 幾らかはデバ イスを透過できることになる。そこで問題は ON 状態でどれ程の透過光が得られるかということ である。

この問題を明らかにするために，液晶分子の 方向を層に垂直な方向に沿っての位置とデバイ スへの印加電圧の関数と考えよう。四 6 はツイ スト配向のデバイスにおける液晶分子のツイス ト角とティルト（傾斜）角を液晶層内の位置の 関数として計算した結果を示している。同図か ら分るように，電圧印加は螺施状のツイストを なくする効果を持っている。理想的な場合には, 電圧を印加したとき, 液晶層の半分では分子は 一方の電極板の配向処理方向に配向し，他の半 分ではもう一方の電極板の配向処理方向に配向 する。

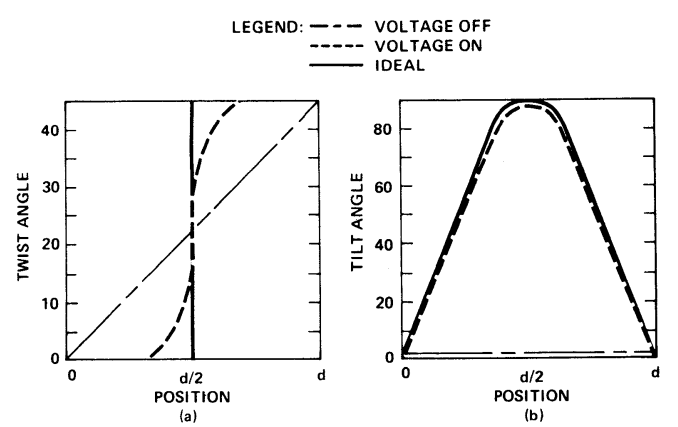

図 6 液晶層内での分子軸方向の計算結果 : (a)ツイスト 角，(b)ティルト角（文献 2)

実際のツイストネマティックデバイスにもこ のような理想的な分子配向分布に近いツイスト 角分布を実現する電圧範囲が存在するが，それ
は物理的には次のように説明できる。液晶分子 のツイストは液晶のもつ “長” 距離分子間配列 カによりある薄い層から次の層へと伝達される。 一般に, 液晶分子のティルト（傾斜）角が大き くなれば（基板に垂直に近くなれば），このッ イストの層間の伝達力は弱くなる。もし液晶に 電極板に垂直に配列した層があれば，ここでは ツイストは全く伝達されない。このような層は 全体の螺施状ツイストを2つに切ってしまう効 果を示す。実際にこうした効果を生じれば，液 晶は近い方の電極板の配向処理に従った方向に 配向して安定する。これはすなわち理想的に近 いツイスト角の分布（図6(d)）を実現すること に他ならない。

ティルト（傾斜）角 $(\theta)$ を液晶セル厚さ方 向の位置の関数として計算した結果を図 $6(\mathrm{~b})$ に 示す。電極に近い位置ではティルト角は小さい が, 液晶層中心ではティルト角 $(\theta)$ は分子間傾 斜角の液晶セル厚さの半分にわたっての総和に 等しいので大きな值となっている。閾値の 2 倍 の電圧でも, 液晶セル中心でのティルト角は $80^{\circ}$ にもなる。このようにして液晶に加えられた比 較的低い電圧でも螺施は切れてッイスト角の分 布は図 $6(\mathbf{a})$ の理想的なものに近くなるのである。 更にこの理想に近い状態では平均のティルト角

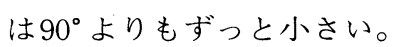

デバイスはこの状態での複屈折を以下のよう に利用したものである。ッイストネマティック 効果のOFF状態を実現するため, デバイスに入 射する光の偏光は入射側電極板の配向処理方向

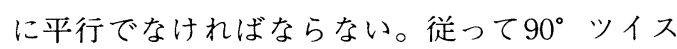
トのセルでは, ツイストが切られたとき偏光方 向は大部分の液晶分子に対して $0^{\circ}$ と $90^{\circ}$ の角を なし, 複屈折は非常に小さい。このことから明 らかなように, 複屈折を(少くとも1次のオー ダで）最大にするには 2 枚の電極板の配向収理 方向を互いに450の角をなすようにすればよい。 このときデバイスの O N状態での光透過率は最

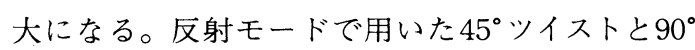
ツイストのネマティック液晶セルの特性には図 7 に示すように顕著な違いがみられる。 


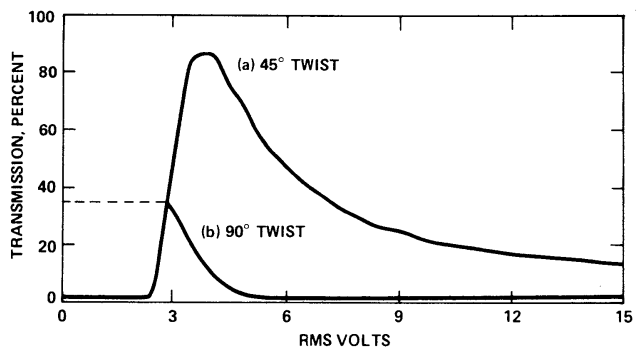

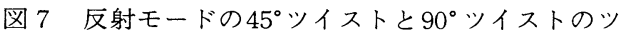
イストネマティックセルの電気光学効果の比較

\section{CdS 光入力型液晶光バルブ}

\section{A. 構造}

一般的なデバイス構造を図 8 に示す。この交 流光バルブは 2 板のガラス板にはさまれた数層 の薄膜で構成されている。低圧（ $\left.5 \sim 10 \mathrm{~V}_{r m s}\right)$

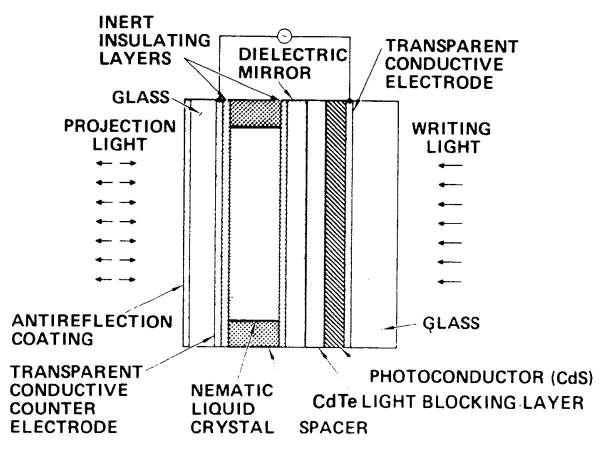

図 $8 \mathrm{CdS}$ 液晶光バルブの断面図

の低周波電源が多層構造の両外側の $\left(\mathrm{InO}_{2} / \mathrm{S}_{n} \mathrm{O}_{2}\right.$ （ITO）薄膜透明電極に接続されている。フォ トコンダクタ (光伝導体) の硫化カドミウム $(\mathrm{CdS})$ と遮光層のテルル化カドミウム $(\mathrm{CdTe})$ は整流性のへテロ接合を構成している。フォト コンダクタは誘電体ミラーと遮光層により読み 出し光の影響を受けない構造となっている。こ の構造により, デバイスは書き込み光・読み出 し光の波長に関係なく書込みと読み出しを同時 に行なうことができ，これがこの交流光バルブ の大きな特徵である。又, 誘電体ミラーが液晶 内を直流電流が流れるのを阻止しているため, デバイスは長寿命である。更に, 誘電体ミラー
の反射波長域を適当に選ぶことにより：ミラー の分離効率を最適化するとともにデバイスの反 射率を最大にすることができる。液晶層は化学 的に安定な $\mathrm{SiO}_{2}$ 絶縁層の間に封入されている ため, デバイスは非常に長寿命である。なおこ のデバイスに用いた液晶はビフェニール系のネ マティック液晶である。*

B. 動作

デバイスの動作を図 9 に示す理想的な光バル ブ基板**の等価回路を用いて説明する。同困で,
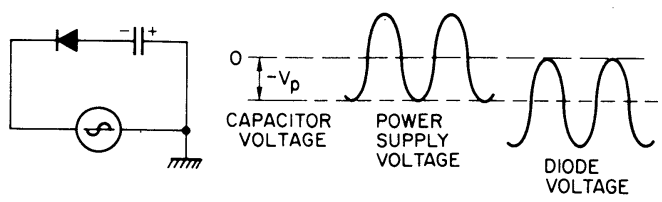

図 9 入力光が入射しないときの理想化した光バルブ “基板”の等価回路と電圧波形

ダイオードは CdS/CdTeへテロ接合ダイオー ドを表し，キャパシタは誘電体ミラーのキャパ シタンスを表す。この図はOFF状態, すなわ ち, CdS光センサに入力光が入射しない場合を 表したものである。この回路に交流電圧を加え れば, キャパシタは最初の周期で電源の負のピ 一ク電圧 $\left(-\mathrm{V}_{p}\right)$ まで充電される。この電圧は 正弦的な電源電圧の全ての值に対してダイオー ドの逆バイアスとなる。もしダイオードの逆方 向抵抗が無限大ならば, 電源電圧が周期的でさ えあれば，その周波数，波形，振幅にかかわら ず，回路に流れる定常状態の電流は常に0であ る。従って理想的な液晶光バルブの入力光が入 射しない部分では電流は全く流れない。

さて, 次に入力光が入射する部分について考 えよう。理想化した回路では, 光入射により困 10(a)のようにダイオードに並列に漏れ抵抗が生 じることになり, キャパシタはダイオードが逆 バイアスされるサイクルでこの漏れ抵抗を適し て放電する。この時の電圧・電流波形はそれぞ れ図 $10(b) ，(c)$ のうになる。電源周波数が十分

\footnotetext{
* British Drug House mixture E-7

**光パルブ “基板” とは光伝導体, 遮光層および誘電体 ミラーからなる薄膜構造の部分をさす。
} 


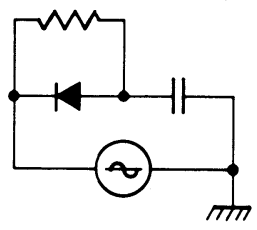

(a)

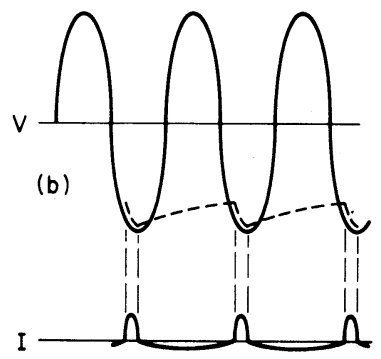

(c)
四10 入力光が入射したときの理想化光バルブ “基板” の等価回路と電流波形

低く，電流が十分大きければ，光入射した部分 の液晶にはその電気光学閥値を越す電界が印加 され，スイッチングが起る。この結果，書き込 まれた画像を投射ビームによって読み出すこと ができる。

実際の光バルブにより近い等価回路を図11に 示す。ここで $\mathrm{R}_{1}, \mathrm{C}_{1}$ はそれぞれ液晶の抵抗とキ ヤパシタンスを表わし, $\mathrm{C}_{2}$ はミラーのキャパシ タンスを表わす。更に $\mathrm{R}_{4}$ と $\mathrm{R}_{3}+\mathrm{R}_{4}$ および $\mathrm{C}_{3}$ は それぞれダイオードの順抵抗と逆抵抗およびキ ヤパシタンスを表わしている。ミラーの漏れ抵 抵 $\mathrm{R}_{2}$ が極めて大きいとすれば， $\omega$ を電源の基本 角周波数として $\mathrm{R}_{2} \mathrm{C}_{2} \omega \gg 1$ が成立し, 回路中 $\mathrm{R}_{2}$ の効果は無視できる。理想的な回路とは異な り，図11で表わされる回路ではフォトコンダク

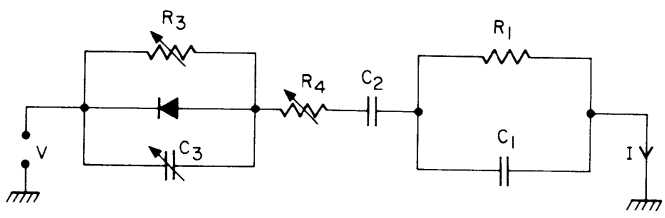

図11 実際の光バルブの等価回路

夕に光が当たらない場合でも多少の電流が流れ る。この回路で光が入射すると $\mathrm{R}_{3}$ と $\mathrm{R}_{4}$ の值は 減少し $\mathrm{C}_{3}$ は増加（接合のフォトキャパシタンス 効果による）する。その結果，光の当った部分 での電流は当らない部分より大きくなる。フォ トコンダクタにより液晶の電気光学効果を制御 することができるのはこの電流の違いのためで ある。従って, 光の当らない部分で電流は液晶
の䦭值レベルより小さく, 光の当っている部分 では液晶分子をスイッチングするのに適当な值 だけ闇值より大きな電流が流れるようにデバイ スの “基板”を設計しなければならない。この 電流比は光バルブの光電効率を決めるものであ るので, 著者らはこれをデバイスのスイッチン グ比と呼ぶが，一般的にデバイス設計の目標は この比を最大にすることにある。

フォトコンダクタの CdS はスパッタによって 作製される多結晶の薄膜であるが，ストイキオ メトリ（化学量論的組成）からのずれや多くの 格子欠陥をもっており，このためキャリアトラ ップの密度は比較的大きい。又, $\mathrm{CdS}$ は $2.4 \mathrm{eV}$ という大きなバンドギャップエネルギーを持つ 半導体であり，このバンドギャップ中には長寿 命のキャリアトラップも存在する。このためフ オトコンダクタの応答は遅くなるが, キャリア トラップは光電流のゲインを生み出すという重 要で有益な役割をも果たしており，このゲイン がなければデバイスは満足に作動しない。図10 から分るように殆んどのサイクルでダイオード は逆バイアスになっている。この逆バイアス電 圧の殆んどはCdS層にかかっており, $\mathrm{CdTe} に$ かかる電圧は無視できる位小さい。その理由は $\mathrm{CdS}(20 \sim 40 \mu \mathrm{m})$ はCdTe $(2 \mu \mathrm{m})$ に比べずっ と厚く, 約 100 倍の比抵抗を持っているからで ある。

OFF状態では CdS 層は接合から裏面までの 全域にわたってデプレッション（空乏）状態に なっている。これに光が入射すると電子一正孔 対が生成される。正孔は殆んど直後にトラップ されるが, 電子は比較的自由に移動できるので サイクルが空乏状態の間に全て移動してしまう。 トラップされた正孔が電子と再結合するまでの 寿命は非常に長い。もし電源の周期がトラップ された正好の寿命より短かければ，光生成され た電子はトラップされた正孔と再結合するまで の間の各サイクルごとに何回も生成され移動す る。これがゲインを生み出し, ゲインは駆動周 波数と正孔の寿命に比例する。ダイオードをデ プレッションモードで動作させた時はそうでな い場合に比べてトラップされた正孔の寿命は長 
いデプレッション領域で再結合確率は事実上 0に等しく, 再結合は回復時間内のみで起る。 従ってデプレッションの場合のトラップされた 正孔の寿命は，デプレッションとなる時間の非 デプレッションとなる時間に対する比を乗じた ものとなる実験により，このゲインは $10 \mathrm{KHz}$ で100のオーダとなり，スイッチング比は $100 \mathrm{~Hz}$ から $100 \mathrm{KHz}$ にわたってほぼ定であることが 分った。これは暗電流は主としてキャパシタを 通して流れる電流であるので周波数に比例する のに対し, 光電流はゲインにより流れる電流で あるためである。

表 1. CdS液晶光バルブの性能

TABLE I. CdS LCLV PERFORMANCE

\begin{tabular}{|ll|}
\hline LC MODE & HYBRID FIELD EFFECT \\
CLEAR APERTURE & $46 \mathrm{~mm}$ DIAMETER \\
LIMITING RESOLUTION & 70 LINES $/ \mathrm{mm}$ \\
CONTRAST RATIO & $50: 1$ \\
SENSITIVITY & $50 \mu \mathrm{W} / \mathrm{cm}^{2}$ AT $520 \mathrm{~nm}$ \\
TIME RESPONSE & $100 \mathrm{~m} \mathrm{sec}$ \\
\hline
\end{tabular}

このデバイスの性能を表 1 に示す。デバイス は現在ヒューズ社で半ば製産段階に入っており, 光情報処理のための最も有用なデバイスのひと つと考えられる。

\section{Si 光入力型液晶光バルブ}

\section{A . 構造}

ヒューズ研究所では第 2 世代の液晶光バルブ (LCLV) の開発が最終段階にまで来ている。 この新しいデバイスはフォトコンダクタ（光伝 導体)として高抵抗のシリコン単結晶の薄い( 5 ミル）ウエハを用いたものである。このデバイ スは応答速度, 感度, 分解能および生産性の点 でCdSを用いたデバイスより優れたものとなる 可能性をもっている。

デバイスは図12のようにシリコンフォトコン ダクタと酸化膜層からなるMOS構造を有して いる。誘電体ミラーと遮光層が一体化された構 造は最近開発されたものである，この構造によ り, 強い読み出し光のフォトコンダクタへの影

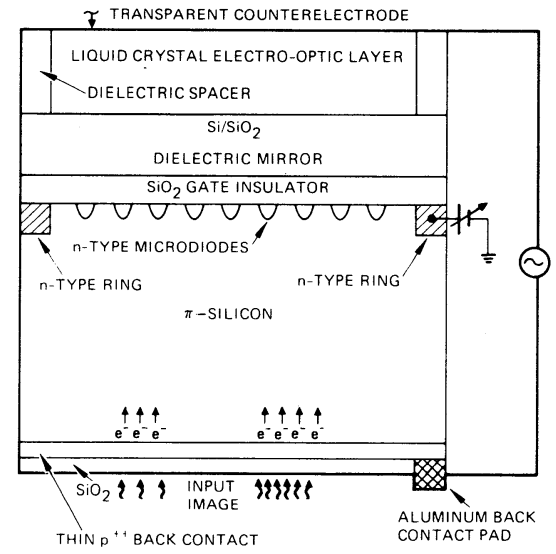

図12 Si 液晶光バルブの断面図

響をなくすると共に, 広い波長域で要求される 高い反射率（90\%以上）を実現することができ る。読み出し光は液晶を通過してこの誘電体ミ ラーによりリトロー反射される。液晶は先に述 ベたハイブリッド電界効果モードで動作する。

B. 動作

MOSの動作モードは周期的なデプレッショ ン（空乏）状態とアキュームレーション（蓄積） 状態からなっている。デプレッション状態(活性 状態）では, 高抵抗の $\mathrm{P}$ 型 $(\pi)$ シリコンは完全 に空乏状態になっており, 入力光により生成さ れた電子生孔対は電界により移動し, 液晶を駆 動する信号電流を生じる。この信号電流によっ て $\mathrm{Si} / \mathrm{SiO}_{2}$ 界面に蓄積された電子は, 電源周波 数周期の終りでパルス的にMOSがアキューム レーション状態になった時に再結合により消滅 する。信号電流電子をウエハ内で（拡散によっ てではなく）電界と $\pi-\mathrm{SiO}_{2}$ 界面にリンの打ち 込みによって作成したn-ルグリッドにより移動 させることにより，シリコンを通した画像も入 力画像と同じ空間分解能を持つようにすること ができる。このグリッドは流入する電子をグリ ッドにより定義される分解単位に集中させる作 用をもつとともに，既に $\mathrm{Si} / \mathrm{SiO}_{2}$ 界面に蓄積さ れた電子の電荷 “容器”を形成する。このため 横方向の “流れ出し”は起こらず, 従って電荷 パターンが鮮明さが失われることはない。シリ コンウエハの周辺部には周囲から活性領域へ少 
数キャリアが注入されるのを防ぐためダイオー ドガードリングが設けられている。光変調器に は応答速度が速く正の誘電異方性をもつた液晶 によるツイスト角 $45^{\circ}$ の薄い液晶層が用いられ ている。入力電極は $\mathrm{InO}_{2} / \mathrm{SnO}_{2}$ を被着したファ イバオプティックフェイスプレートである。前 面ガラス上の電極上には $\mathrm{InO}_{2} / \mathrm{SnO}_{2}$ 導電層と液 晶スペーサが埋積されている。全体は陽極酸化 したアルミニウムの気密ホルダ内に組立てられ ている。

フォトコンダクタや薄膜構造およびシリコン プロセスなど最近の技術発展により，デバイス の分解能, コントラスト比および応答速度は相 当改善されてきている。現在の性能の詳細を表 2 に示す。又, 代表的な時間応答と幾つかの Si -LCLVのMTFカーブをそれぞれ眓13と14に示 す。

\section{表 2. Si液晶光バルブの性能}

TABLE II. PERFORMANCE OF Si/LCLV

- RESOlUtion: 70 LINES/mm (LIMITING) (FOCUSING GRID-10 $\mu \mathrm{m}$ PERIODICITY)

- SENSITIVITY UP TO $20 \mu \mathrm{W} / \mathrm{cm}^{2}$

- contrast ratio: up to 100:1

- RISE/DECAY TIMES 5/20 ms (LC - LIMITED)

- Nonlinear ReSPONSE: BetTER THAN 10\% IN 80\% OF OPERATIONAL REGION

- Very good REAL-TIME tV PROJection (LAg FREe operation)

- MULTIMOde (PSEUdo COLOR) CAPABILITY: 2 COLORS + GREY SCALE

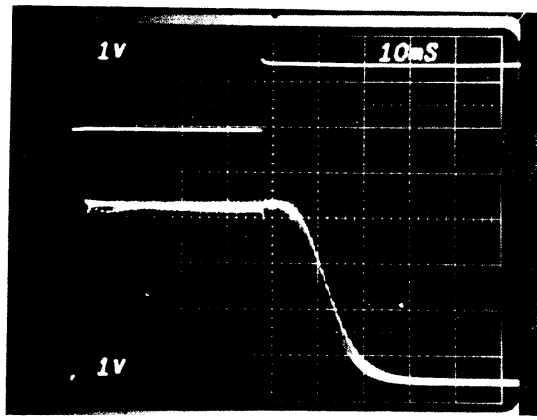

図13 $\mathrm{Si}$ 液晶光バルブの時間応答 上側 : 入力 $\mathrm{LED}$ 光パルス (負レベル $=\mathrm{OV})$ 下側 : 出力光応答 立上り時間 $=4 \mathrm{msec}$, 立下り時間 $=22 \mathrm{msec}$

現在継続されている研究の課題は

(1)出力像の均一性の改善, (2)遮光層の遮光能力 の改善，(3)高い空間周波数域の変調度（図14参

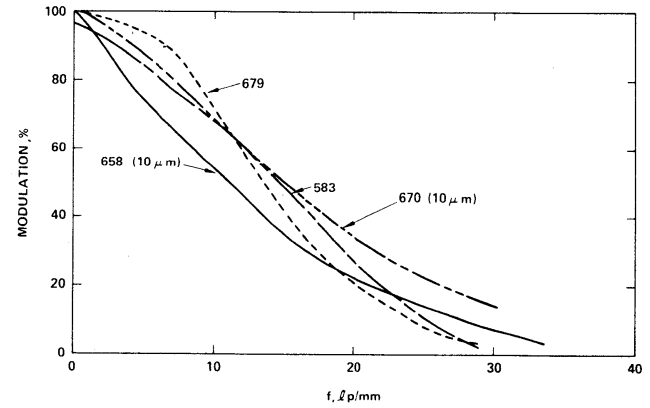

図14 幾つかの Si液晶光バルブの変調伝達関数 $(\mathrm{MTF})$

照）を高めるためのSiプロセスの改善 などである。

\section{CCDアドレス液晶光バルブ}

このデバイスは液晶光バルブ $(\mathrm{LCLV})$ の第 3 の世代であり, 現在ヒューズ研究所で開発が 進められているものである。このデバイスは, 電気的に駆動されるもので，従って入力デイス プレイ（すなわち CRT）が不必要であるという 点で先に述べた2つの LCLVと異なっている。 この CCD/LCLVは光情報処理システムをより 小型・堅牢にすることを主眼に開発されている。 デバイスの機能の概略を図15に示す。CCD （電荷結合デバイス）回路は時系列の電気信号 を 2 次元の情報フレームに変換し C C Dアレイ 内に電荷パケットとして蓄積する。最初に情報

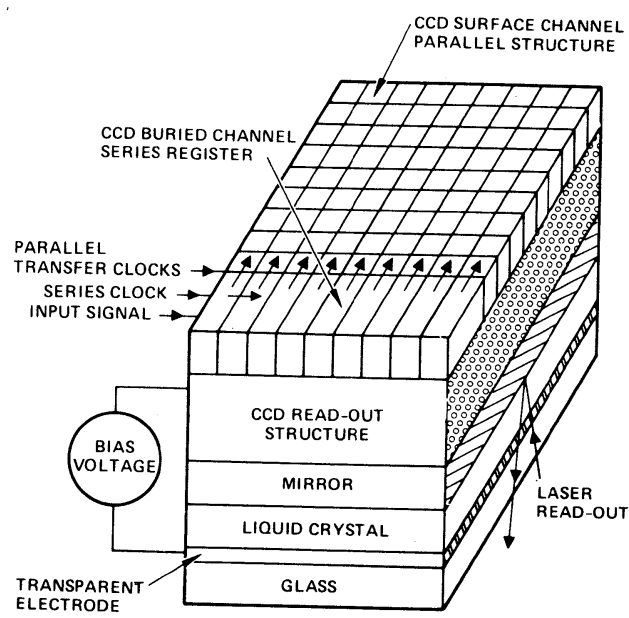

図15 CCD入力液晶光バルブの構造 
の 1 ラインがCCDのシリアル入カレジスタ（ $\mathbf{x}$ 方向）にロードされ，このレジスタが満たされ るとこのラインの情報全体が CCDのパラレル アレイにパラレルに転送（y方向）される。次に シリアルレジスタに新しい 1 ラインの情報が入 力される。更に第 1 ラインの情報がパラレルア レイ内で 1 段シフトされると同時に第 2 ライン の情報がシリアルレジスタからパラレルアレイ の第 1 段に転送される。この過程がパラレルア レイに情報フレーム全体が満たされるまで繰り 返される。最後にフレーム全体が同時に液晶層 へ転送（ $\mathrm{z}$ 方向）され，空間的に分解された電 圧変調パターンとなる。この転送はパラレルC C Dアレイのゲートを全て同時にアキュームレ ーションにバイアスし，蓄積していた電荷パケ ットを放出することによってなされる。この空 間的なパターンをなす電子電荷は, 薄いエピタ キシャル層内をデバイスの高抵抗シリコン基板 側まで拡散した後，完全に空乏状態となってい る基板の空間電荷領域の電界により捕集される。 この変調は，C C Dパラレルアレイに新しい情 報フレームが入力される間，一時的に液晶層に 保持される。このデバイスからの光学的読み出

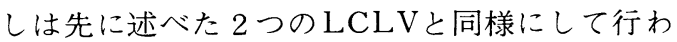
れる。基本的な C C D光バルブの読み出し機構 の断面困を困16に示す。信号電荷がC C Dパラ レルアレイから液晶界面に移される際には, 薄

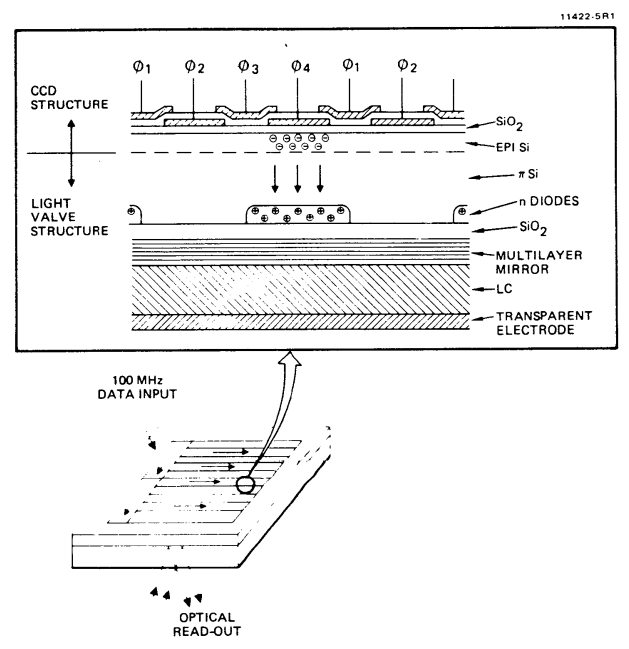

図16 CCD液晶光バルブの断面図 w $(125 \mu \mathrm{m})$ 高抵抗 $(5 \mathrm{~K} \Omega \cdot \mathrm{cm}<\rho<10 \mathrm{~K} \Omega$. $\mathrm{cm})$ の $\pi$ - シリコン基板は低抵抗 $(1 \Omega \cdot \mathrm{cm}<\rho$ $<50 \Omega \cdot \mathrm{cm})$ のエピタキシャル層まで完全に空 乏状態となっている。この転送は空乏層の電界 によってなされるが，電界分布はC C D面に垂 直であるので（先に述べた $\mathrm{Si} / \mathrm{LCLV}$ と同様に）

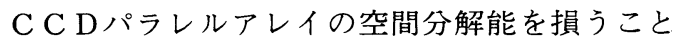
なく行われる。シリコンエピタキシャル層は中 程度の比抵抗をもち, 表面チャンネルC C D の レジスタとストレージアレイを作製するのに適 している。低抵抗のチャンネルストップは主と して隣接する C C D インを分離する役割を果 たす。これはまたエピタキシャル層へのオーミ ックコンタクトでもあるので, エピタキシャル 層は読み出しのための液晶へのバイアスに対し て Siチップの CCD側の種々の電気信号をシー ルドするための電気的な接地面としても用いら れている。

以上で説明したように，このデバイスには 2 種類の全フレームの蓄積機構がある。第 1 は C C D アレイであり第 2 は液晶であるが, 後者は ほぼ指数関数的に消失する性格をもっている。 このため, C C D ストレージを時系列の入力信 号をパラレル型式に変換し, その後フレーム全 体をパラレルに液晶（第 2 のストレージ）と光 処理システムに転送するために用いることがで きる。このことは全ての画素が同時に表示され る必要のあるコヒーレント光情報処理では非常 に重要なことである。 $64 \times 64$ エメントのCCD 光バルブが既に作製され，その動作が確認され ている。これらのデバイスではフレーム全体で 32 本の読み出し空間分解能と $50 ： 1$ 以上の読み 出しコントラスト（図17参照）が得られている。 この基本設計を拡張してフレーム当り $256 \times 256$ エレメントの空間分解能を達成する試みが現在 なされており，最初のデバイスが 2 ケ月以内に 完成する予定である。長期にわたっては100M $\mathrm{Hz}$ の入力を処理できる $1000 \times 1000$ アレイのデ バイスを目標と考えている。

\section{6. 応用}

一般的に言ってこの種のデバイスは汎用性が 


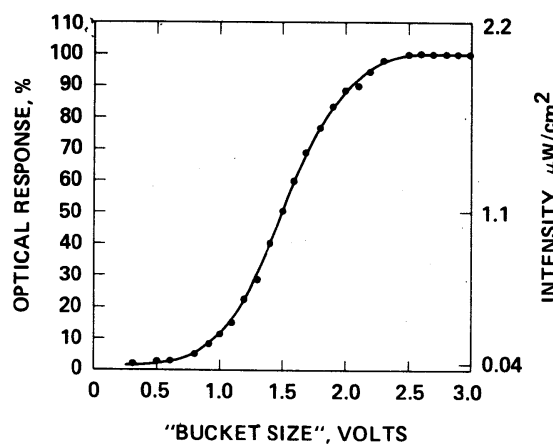

図17 CCD液晶光バルブの電気一光学伝達関数, 横軸 : ゲート電圧 $V_{\text {gete }}$ で表した入力信号電荷（ $Q_{\text {in }}$, $\left.\mathrm{Q}_{\text {in }}=\mathrm{C}_{\text {ox }} \mathrm{V}_{\text {gate }}\right)$.

あり，作製過程を少し变えれば，多くの異なつ た用途に用いることができる。最も重要な応用 はもち論, 大スクリーンのディスプレイシステ ムである。これらのディスプレイシステムは, コマンド・コントロールのためのカラーシンボ ル表示やフライトシミュレーション用のテレビ ジョンその他多くの応用が考えられる。

A.コマンド・コントロール

この種のシステムは文献 1 に述べられている もので, また罒1にも示したように1個の単電 子鏡 CRTと 1 個の光バルブから構成されている。 $\mathrm{CRT}$ 上の輝度の違いがスクリーン上で異なった 色として表示される。CRT上の空間的な輝度分 布は液晶に加わる電圧の分布に変換され, 液晶 層の実効的複屈折の空間的な分布が生じる。実 効的な複屈折 $\Delta \mathrm{n}$ と液晶の厚さ $\mathrm{d}$ の積で与えられ る光路差が比較的大きいので, 位相差 $(\Delta \mathrm{nd}$ ) $\lambda$ ）は光の波長 $(\lambda)$ によって著しく異なり，こ のためある波長の透過率は大きく他の波長に対 しては小さくなる。液晶の透過スペクトルは図 18のようになるが，この範囲で色が良好に識別 されシンボル表示に適するような動作点を何点 か選ぶことができる。さらに，基板に垂直な配 向をも利用すれば，同時にハーフトーンを含ん だ明暗の画像をも作り出すことができる。”ッイ ストネマティック配向の場合にはスペクトルは 更に複雑なものになる（計算は文献 6 と 7 に述 べられている)。必要となる大きな光路差を得る ための液晶厚さは $6 \sim 15 \mu \mathrm{m}$ である。この方法

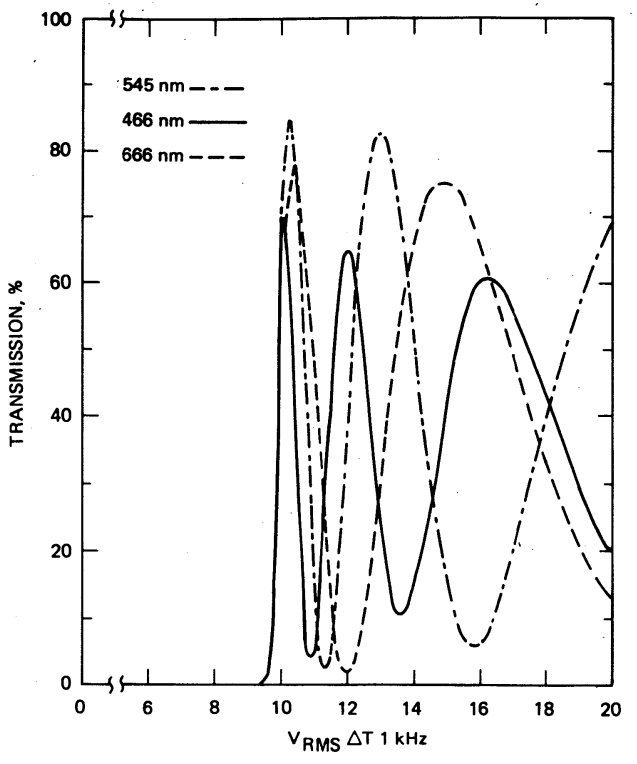

罒18 基板に垂直に配向（ホメオトロピック配向）し 液晶層の透過スペクトル

により非常に簡単な多色システムが実現できる が, 応答速度が50 $200 \mathrm{msec}$ と比較的遅い。し かし，この応答速度でもシンボルディスプレイ には十分に用いることができる。CdS光バルブ を用いたこのシステムは市販されている。

B. テレビジョン

この場合は高速で多色かつハーフトーンを含 む応答が必要である。このため図19のような 3 チャンネルの色混合システムが用いられる。 3 原色がダイクロイックフィルターにより選択さ れ, McNeilビームスプリッターにより重ね合 される。このシステムの重要な利点は全てのコ

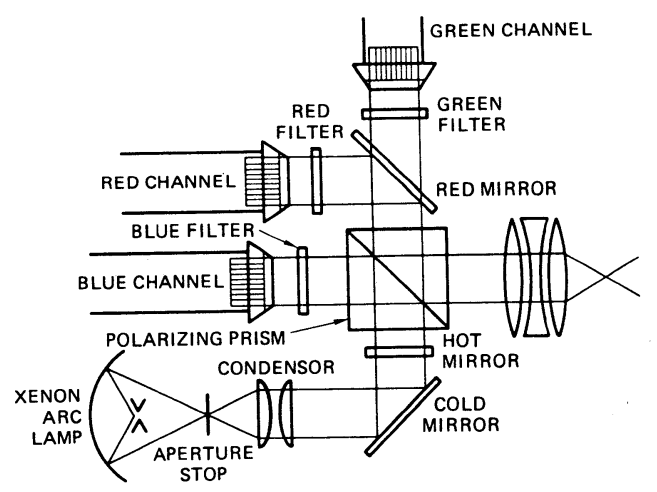

図19３チャンネル色混合システム 
ンポーネントが光軸上にあることで, 従ってシ ステムを画素の精度で軸合わせすることが比較 的容易なことである。このタ々プのシステム

（CdS 光バルブを用いたもの）は既に作製され ており，近く市販されることとなろう。

C. 光情報処理

光学的な情報処理の重要な応用領域は広帯域 時系列信号の処理と 2 次元情報又は画像情報の 処理である。光入力型のデバイスは画像処理に 有効に利用でき ${ }^{5,8,9)} \mathrm{CCD}$ 入力型空間光変調器 は両方の領域に応用できる。CCD-LCLVの特 に重要な応用はレーダーの信号処理であり，こ れには“ぼけ”関数発生や合成開ロレーダー

(SAR) 処理も含まれる。

2 個の液晶光バルブを用いた “添け” 関数発 生システムについては既に報告があるが, 光入 力型の LCLVをCCD入力の LCLVに置き換え ることにより C R T や音響光学ユニットを用い る必要がなくなりシステムは格段に改善される であろう。

最近NOSCの研究者により, 合成開ロレーダ - (SAR) のための電気一光学プロセッサー (EOP)にCCD-LCLVを援用することが提案さ れた。EOPの原理は高速の LEDを入力に用い, 時間的に変化する L E D 発光強度と適当な 2 次 元透過マスクの相関をとることによるRangeA zimuthの処理である。 ージセンサを用いてマスクを透過した空間的に 変調された光強度を積分することにより得られ る。このシステムでCCD-LCLVをプログラマ ブルマスクとして用いれば（図20），フライト 条件や，ターゲットの性格等を種々に変化させ ることができ，リアルタイムで相関をとること ができる。もう一つのCCD-LCLVの有効な応 用にスペクトル分析があげられる。この場合 CCD-LCLVは（リアルタイムの） $100 \mathrm{~Hz} の>$ レームレートのとき $100 \mathrm{MHz}$ 以上の帯域で $10^{6}$ 点の分解能を得ることができるであろう。必要 なパワーとサイズを考えに入れれば，このよう な性能は開発中の最新のディジタル技術 $(\mathrm{VH}$ SIC) でさえも達成することはできないであろ う。

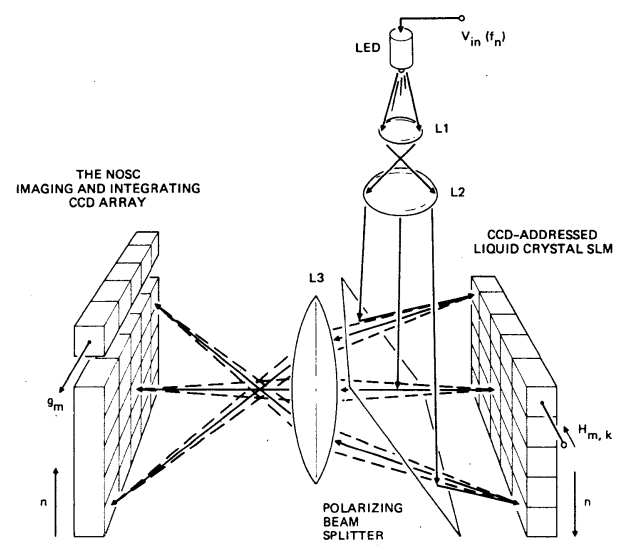

図20 CCD夜晶光バルブを用いた電気一光学プロセッ サー（LEDはダイオード列のうちの 1 個を示して (る)

コヒーレント光相関システムはフライトガイ ド，標的検出・認識を行えるような設計が可能 である ${ }^{11}$ ホログラフィックマッチドフィルタ技 術を用いた最初の実験では明るい見通しが得ら れている ${ }^{12}$ 大部分の画像センサシステムでは時 系列のビデオ電気信号が出力されるが, この信 号はCCD-LCLVに入力することができる。

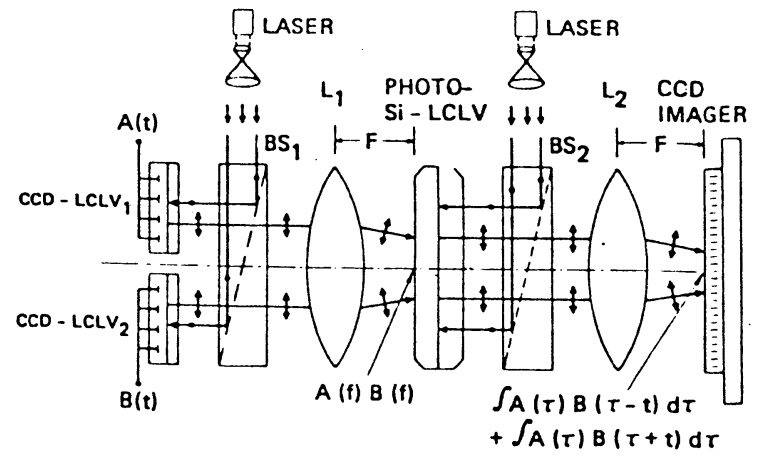

図21 CCD入力と光入力型の液晶光バルブを用いた結 合変換法による画像相関システム

上述の応用のための画像と参照パターンの相 関を行う一例を図21に示した。ここで解析する 画像 $\mathrm{A}(\mathrm{t})$ (ビデオ型式）と参照画像 $\mathrm{B}(\mathrm{t})$ の相 関演算が結合変換法 ${ }^{13)}$ により行なわれる。2 個 のCCD-LCLVはフーリエ面で乗算されるコヒ ーレントなリアルタイム光画像を発生するため の電気一光学変換器として用いられており, 光 
入力型の Si-LCLVは乗算された画像を再変換 することにより求める相関を得るために用いら れている。

解析される画像を Si-LCLV上に直接結像さ せることのできる場合もあるが，Si-LCLVは 450〜 550n m の波長域で $50 \mu \mathrm{W} / \mathrm{cm}^{2}$ 程度の感度 をもち，実際には400nmから1100nmまでの広い 波長域で用いることができる。この場合, SiLCLVの直接画像出力およびインコヒーレント 一コヒーレント変換の機能を有効に利用するこ とにより，入力画像をビデオ信号で記録・読出 しする必要はなくなる。

\section{D. 可視一赤外画像変換器}

この応用では光バルブは波長変換器の機能を 果たす。一般にこのデバイスは可視動画を赤外 動画に変換する。赤外イメージセンサシステム の試験と評価がその目的の一つである。

これを具体化したシステム ${ }^{14)}$ では光バルブは 透過モードで作動させる。この場合, 反射モー ドより透過モードの方が（1)非常に長い $(10 \mu \mathrm{m})$ 波長域では誘電体ミラーの作製が非常に困難で ある，(2)光伝導体 $(\mathrm{CdS}, \mathrm{Si})$ は長波長に感度 を持たないので透過モードで使用できる，の2 つの理由で適している。 $\mathrm{CdS}$ や $\mathrm{Si}$ は赤外光を 良く透過させるが, ガラス基板は通常のものに 代って赤外域で透明な材料（例えば $\mathrm{ZnSe}$ ）に 置き換えなければならない。又，液晶は $\left(45^{\circ}\right.$

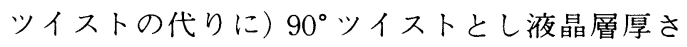
を適当に選ぶ必要がある。優れた性能のシステ ムが開発されている。

以下のコントラクトによる開発援助に感謝す る。F 33615-80-C-1019 (AF/AWL), F 33615-81-C-0018 (AF/HRL), N0002476-C-5366 (NAVSEA)。

\section{参 考 文 献}

1) Jan Grinberg, William P. Bleha, Alexander D. Jacobson, Anna M. Ladner, Gary D. Myer, Leroy J. Miller, J. David Margerum, Lewis M. Fraas, and Donald D. Boswell, IEEE Trans. ED - , 775-793 (1975) .

2) D. W. Berreman, J. Opt. Sci. Am. 63, 1374 (1973).

3) L. M. Fraas, J. Grinberg, W. P. Bleha, A. D. Jacobson, J. Appl. Phys. 47, 576 (1976).

4 ) L. M. Fraas, W. P. Bleha, A. D. Jacobson, J. Appl. Phys. 47, 584 (1976).

5 ) W. P. Bleha, L. T. Lipton, E. Wiener-Avnear, J. Grinberg, P. G. Reif, D. Casasent, H. B. Brown, B. V. Markevitch, Opt. Eng 17, No. 4 . 371 (1978).

6) J. Grinberg, A. D. Jacobson, J. Opt Soc. Am 66, 1003 (1976).

7) E. Wiener-Avnear. To be published.

8) J. Grinberg, A. D. Jacobson, W. P. Bleha, L. J. Miller, L. M. Fraas, Opt. Eng. 14, 217 (1975).

9) J. Grinberg and E. Marcus, Proc. SPIE 118, 66 (1977).

10) K. Bromley, M. A. Monahan, R. R. Bocker, A. C. Louie, and R. D. Martin, "Incoherent Optical Signal Processing Using ChargeCoupled Devices (CCDs)," SPIE 118, 118 (1977).

11) K. G. Leib, R. A. Bondurant, S. Hsiao, R. Wohlers, and R. Herold, “Aerial Reconnaissance Film Screening Using Optical Matched-Filter Image Correlator Technology," Appl. Opt. 17, 2892 (1978).

12) B. D. Guenther, C. R. Christensen, and J. J. Upatnieks, "Coherent Optical Processing: Another Approach," IEEE J. Quantum Electron, QE-15, 1348 (1979).

13) J.E. Rau, "Detection of Differences in Real Distributions," J. Opt. Soc. Am. 561490 (1966).

14) J. Grinberg, U. Efron, M. J. Little, W. P. Bleha, Proc. SPIE 226, 129 (1980). 